\title{
Elanex battles for a piece of the erythropoietin market
}

On November 18, 1997, Elanex (Bothell, WA) was issued US patent 5,688,679 for an Apa I restriction fragment of the human erythropoietin (epo) gene-designated epoetin omega by the World Health Organization (WHO; Geneva, Switzerland). Elanex has also received related patents in over 20 countries outside the United States, where it has been selling epoetin omega under the trade names EPOMAX and HEMAX since 1990. EPOMAX has been received favorably, cornering up to $50 \%$ of the EPO market even in countries where Amgen's EPOGEN was introduced first, says Elanex's counsel Ybet Villacorta of Lowe, Price LeBanc \& Becker (Arlington, VA).

Until now, many thought that Elanex's epoetin omega unequivocally infringed Amgen's (Thousand Oaks, CA) patents on erythropoietin-designated epoetin alpha by WHO. Elanex's new patent, however, reveals differences between the two EPO genes, including differences in the nucleotide and amino acid sequences. A new US patent issued to Elanex Pharmaceuticals (Bothel, WA) has sparked new interest in the patent infringement law suit filed in the Western District of Washington at Seattle by Amgen against Elanex back in 1993.

"The issuance of the recently filed Elanex patent has nothing to do with whether they infringe our patent. There is no question that they do infringe our proven DNA patent," says Lynne Henderson, associate manager at Amgen.

Elanex's patent, which was originally assigned to the University of Washington

Ken Chahine is a patent attorney in Salt Lake City,UT(chahine@mmlaw.com).
(Seattle, WA), is a result of numerous continuation applications dating back to 1986 . The Apa I gene fragment is only 2426 base pairs (bp) -all but 58 bp of the $5^{\prime}$ untranslated sequence and $222 \mathrm{bp}$ of the $3^{\prime}$ untranslated region have been deleted. Elanex's patent states that a "surprisingly high expression of erythropoietin is achieved by transfecting host cell lines with the Apa I restriction fragment of the human erythropoietin." Elanex believes its higher yields are a result of deleting certain "interfering sequences" in the $5^{\prime}$ untranslated region of the gene.

Epoetin omega also has a different nucleotide and amino acid sequence than Amgen's epoetin alpha. In its patent, Elanex claims that the nucleotide sequence of epoetin omega is "essentially the same as that ... published by Jacobs et al." (Nature 313:806-810, 1985). A comparison between epoetin omega and epoetin alpha reveals several nucleotide differences, including a $\mathrm{G}$ to $\mathrm{C}$ point mutation that leads to a glutamic acid to glutamine substitution at position +13 of the mature EPO gene. In addition, epoetin alpha runs approximately $15 \%$ slower on SDS PAGE than epoetin omega, suggesting possible posttranslational differences. These differences might explain Villacorta's claim that EPOMAX sometimes elicits responses in patients that do not respond to Amgen's epoetin alpha.

Do these differences place EPOMAX beyond the scope of Amgen's patents? The 1993 complaint against Elanex asserts infringement of Amgen's 4,703,008 patent (the '008 patent) —although Amgen can likely amend its complaint to assert infringement of its recently issued EPO patents. Claim 2 of that patent, which Elanex states is one claim
Amgen avers is being infringed, covers " $[\mathrm{a}]$ purified and isolated DNA sequence ... encoding human erythropoietin." While the claim could be taken to cover epoetin omega, the fact that Amgen does not disclose the nucleotide sequence of epoetin omega may prove fatal particularly in light of a recent ruling on the written description requirement (Nature Biotechnology 15:823, 1997).

Claims 7, 8, 23-27, and 29 of the '008 patent would certainly encompass omega and the host, as they cover not only nucleotide sequences that encode an epoetin alpha, but also sequences that are "sufficiently duplicative" to EPO and that retain biological activity. These claims, however, were invalidated because they were not enabling in Amgen's law suit against Chugai Pharmaceutical (Tokyo, Japan) and Genetics Institute (Cambridge, MA).

Nevertheless, even if epoetin omega does not directly infringe any of the claims of the '008 patent, Amgen can argue that the differences between the two sequences are insubstantial and merit a finding of infringement under the judicially created doctrine of equivalents.

In addition to direct infringement by Elanex, Amgen has named Laboratorios Elanex De Costa Rica, Bio Sidus (Buenos Aires, Argentina), Merckle GmbH (Ulm, Germany), Biosintetica (Sao Paulo, Brazil) and "other unknown defendants that have entered into agreements with Elanex relating to rEPO and have "induced Elanex to provide infringing host cells made ... for their use and benefit." Under US patent law, one who aids another's infringement is liable as the infringer.

Ken Chahine

Table 1. Major US law suits involving Amgen's erythropoietin.

Lawsuit
Amgen versus Chugai Pharmaceutical and
Genetics Institute for cross-patent infringe-
ment of their respective erythropoietin patents
Amgen sought to invalidate Gl's patent
no. 5,322,837
Amgen sued Elanex Pharmaceuticals,
Laboratorios Elanex De Costa Rica, Bio Sidus,
Merckle GmbH, Biosintetica, and other
unknown defendants for patent infringement
Biogen (Cambridge, MA) sued Amgen for
patent infringement based on Amgen's
method of making Neupogen
Amgen sued Hoechst Marion Roussel (Kansas
City, MO) and Transkaryotic Therapies
(Cambridge, MA) for patent infringement

\section{Patents at issue}

Amgen's patent no. 4,703,008 and Gl's patent no. $4,677,195$, both covering erythropoietin

Gl's patent. no. $5,322,837$

Amgen's patent no. 4,703,008

covering erythropoietin

Biogen's patent nos. $4,874,702,5,401,642$ and $5,401,658$, relating to vectors, methods for making vectors and expressing closed genes

\section{Filed}

September 9, 1994

October 26, 1993

Amgen's patent nos. 5,547,933, 5,618,698, and $5,621,080$ covering erythropoietin
October 27,1987

\section{Outcome}

Amgen's 4,703,008 patent declared partially invalid. Gl's patent no. $4,677,195$ declared invalid

Gl's patent no.5,322,837 declared invalid

Litigation pending March 10, 1995 Litigation pending April 16, 1997 Litigation pending 